\title{
Pemanfaatan Panel Surya sebagai Penerangan Jalan Umum (PJU) di Kampung Wisata Agrowidya, Rajabasa Jaya, Lampung
}

\section{Ilham Dwi Arirohman*1, Putty Yunesti², Rihardian Maulana Wicaksono ${ }^{3}$, Al Barra Harahap", Afit Miranto5, Devy Arysandi ${ }^{6}$, Yulianti Fatmawati7, Rahmat Ramadhan Wahab $^{8}$}

\author{
1,2,3,6Teknik Sistem Energi, Institut Teknologi Sumatera, Indonesia \\ 4,7Teknik Fisika, Institut Teknologi Sumatera, Indonesia \\ 5,8Teknik Elektro, Institut Teknologi Sumatera, Indonesia \\ *e-mail: ilham.arirohman@tse.itera.ac.id ${ }^{1}$
}

\begin{abstract}
Abstrak
Kampung Agrowidya adalah salah satu kampung percontohan untuk wisata agro berbasis pertanian dan perikanan. Kampung Agrowidya yang terletak di Rajabasa Jaya memiliki sistem bertanam hidroponik dan budidaya ikan tawar pada kolam terpal. Namun, kondisi pencahayaan Kampung Agrowidya khususnya pada malam hari masih sangat minim. Berdasarkan fakta ini dan hasil audiensi dengan masyarakat, maka dilakukan upaya pemenuhan kebutuhan pencahayaan jalan umum di Kampung Agrowidya dengan memanfaatkan tenaga surya. Tahapan kegiatan dimulai dengan pengukuran dan analisis tingkat iluminansi dan dimensi jalan. Hasil analisis menunjukkan bahwa kondisi pencahayaan di jalan utama Kampung Agrowidya masih berada di bawah batas yang direkomendasikan SNI 7391:2008. Dilanjutkan pemodelan menggunakan DIALux dengan tiga jenis lampu LED Philips BRP130, BRP052, dan BRP042. Hasil opsi pemodelan yang paling sesuai dan memenuhi SNI 7391:2008 adalah lampu LED Philips BRP130 dengan tinggi tiang 5 meter dan sudut kemiringan 15º dengan menggunakan suplai listrik dari solar panel $210 \mathrm{Wp}$ dan media penyimpanan energi 140 Ah. Penyuluhan tentang penenarangan jalan umum tenaga surya dilakukan untuk membentuk kader masyarakat yang mampu memanfaatkan energi terbarukan khususnya energi surya. Hasil kegiatan pengabdian pada masyarakat ini memberikan hasil berupa instalasi penerangan jalan umum tenaga surya dan peningkatan pemahaman masyarakat Kampung Agrowidya tentang manfaat penerangan jalan umum tenaga surya.
\end{abstract}

Kata kunci: DIALux, Energi Surya, Penerangan Jalan Umum, SNI 7391:2008

\begin{abstract}
Kampung Agrowidya is one of the pilot villages for agro-tourism based on agriculture and fisheries. Kampung Agrowidya, located in Rajabasa Jaya, have a hydroponic farming system and freshwater fish farming in tarpaulin ponds. However, the lighting conditions in Kampung Agrowidya, especially at night, are still very minimal. Based on this fact and the results of public hearings, the community service was conducted to fulfill the need for public street lighting in Kampung Agrowidya by utilizing solar power. The activity stage begins with measuring and analyzing the illuminance level and road dimensions. The results of the analysis show that the lighting conditions on the main road of Kampung Agrowidya are still below the recommended limit in SNI 7391:2008. Based on the measurement data, modeling was carried out using DIALux using three types of Philips LED lamps BRP130, BRP052, and BRP042. The result of the modeling option that is most suitable and complies with SNI 7391:2008 is Philips BRP130 LED lamp with a pole height of 5 meters and a tilt angle of 15o using electricity supply from a $210 \mathrm{Wp}$ solar panel and energy storage media of $140 \mathrm{Ah}$. Dissemination on solar street lighting is carried out to form community cadres who can utilize renewable energy, especially solar energy. The results of this community service activity provide results in the form of installing solar street lighting and increasing the understanding of the people of Kampung Agrowidya about the benefits of solar street lighting.
\end{abstract}

Keywords: DIALux, Public Street Lighting, SNI 7391:2008, Solar energy

\section{PENDAHULUAN}

Kegiatan pengabdian masyarakat ini bekerjasama dengan kelompok tani di Kampung Wisata Agrowidya. Kampung Wisata Agrowidya yang berlokasi di Sinar Harapan, Rajabasa Raya, Lampung merupakan salah satu desa agro yang berbasis pada pertanian dan perikanan. Mayoritas 
penduduknya adalah petani yang yang menggunakan sistem bercocok tanam langsung ke dalam lahan dan juga ditanam melalui media pot untuk pohon serta bunga-bunga, sedangkan untuk sayur mayur sebagian warga sudah mulai menggunakan sistem hidroponik.

Keberhasilan Kampung Agrowidya mengelola sistem hidroponik ini menjadikan mereka sebagai salah satu tujuan wisata edukasi masyarakat umum khususnya dari siswa sekolah dasar hingga menengah atas. Selain berhasil menjalankan sistem hidroponik, mitra kami juga mengembangkan sistem budidaya ikan air tawar menggunakan terpal.
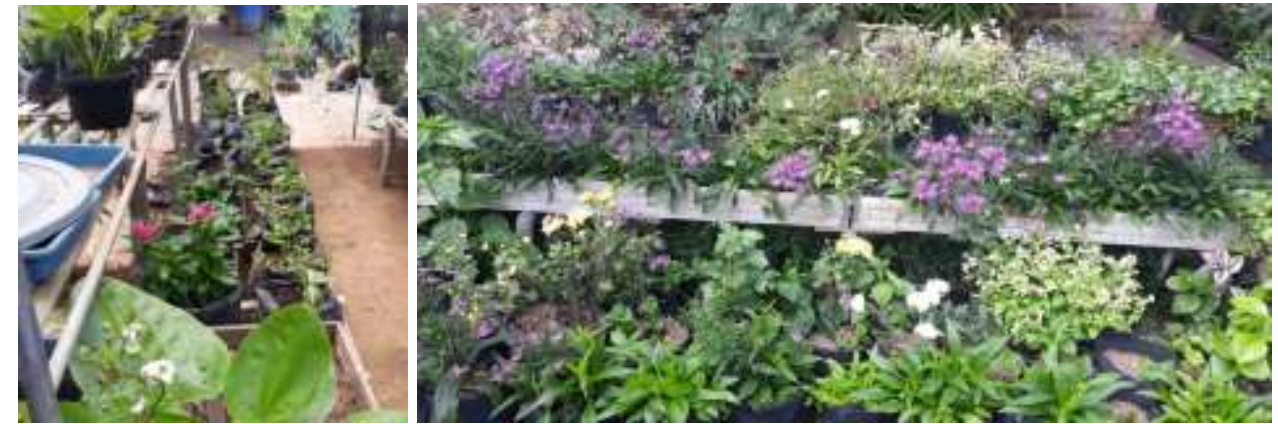

Gambar 1. Sistem hidroponik yang telah dilakukan mitra pengabdian tim pengusul

Kampung Agrowidya merupakan kampung percontohan yang sering dikunjungi oleh masyarakat umum, namun belum memiliki sarana penerangan jalan umum (PJU) yang memadai, seperti yang ditunjukkan pada Gambar 2. Berdasarkan SNI 7391:2008, lampu penerangan jalan umum merupakan salah satu kebutuhan masyarakat yang menjadi kewajiban dan tanggung jawab pemerintah Daerah/Kota sebagai bentuk pelayanan kepada masyarakat. Penerangan jalan umum yang ada saat ini sangat minim dan masih swadaya dari warga yang rumahnya dekat jalan. Fungsi penerangan jalan umum cukup penting antara lain untuk mempermudah pejalan kaki, pemakai sepeda, dan pengendara kendaraan lainnya, untuk melihat dengan lebih jelas jalan/medan yang akan dilalui pada malam hari, sehingga dapat meningkatkan keselamatan lalu lintas dan keamanan dari para pengguna jalan dari kecelakaan maupun kegiatan/ aksi kriminal (Effendi \& Suryana, 2013).

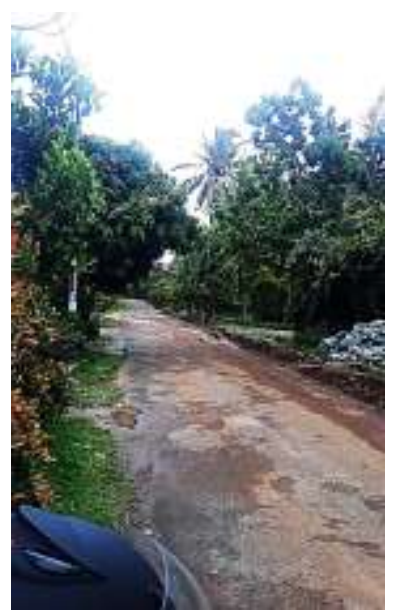

(a)

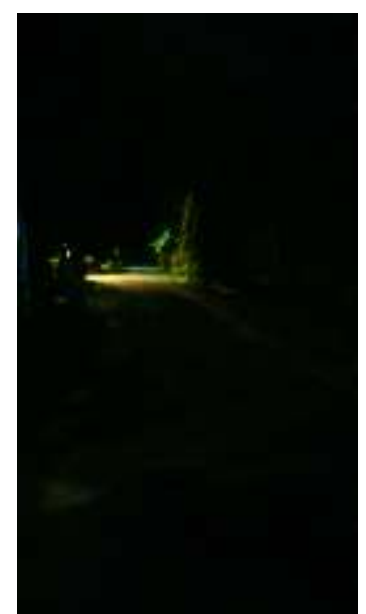

(b)

Gambar 2. (a) Kondisi siang (b) kondisi malam di Kampung Agrowidya yang masih minim penerangan jalan umum

Berdasarkan hasil survei dan diskusi tim pengabdian ke lokasi mitra pengabdian masyarakat, masalah utama yang ditemukan adalah kurangnya prasarana penerangan jalan umum yang memadai di tempat mitra. Oleh karena itu berdasarkan hasil analisis situasi dan diskusi dengan mitra pengabdian masyarakat dapat dirumuskan beberapa masalah sebagai berikut: 
1. Minimnya instalasi penerangan jalan umum

2. Kebutuhan listrik untuk penerangan jalan umum

3. Kurangnya informasi mengenai penerangan jalan umum tenaga surya (PJUTS)

Penelitian sebelumnya yang pernah dilakukan terkait dengan penerangan jalan umum tenaga surya antara lain oleh Asnal Effendi dan Asep Suryana di Kecamatan Sungai Bahar, Kabupaten Muaro Jambi, Provinsi Jambi (Effendi \& Suryana, 2013). Peneliti menggunakan jenis lampu SON-T 150 Watt untuk mencukupi kebutuhan pencahayaan pada jalan dengan tinggi tiang lampu 8 meter, panjang stang ornament 3 meter, kemiringan stang ornament 20,6 $6^{\circ}$ sehingga tingkat pencahayaan sesuai dengan SNI 7391:2008. Peneliti lain melakukan evaluasi terhadap penerangan jalan eksisting di Jalan Soekarno-Hatta Palembang terhadap dua jenis lampu yang digunakan, LED 80 Watt dan SON-T 250. Hasil evaluasinya menyimpulkan bahwa penerangan jalan umum di Jalan Soekarno-Hatta belum sesuai standar (Nurdiana, 2017). Penelitian lain juga menunjukkan bahwa penggunaan dan perawatan penerangan jalan umum tenaga surya di Desa Glanggang, Pakisaji, Malang dapat mengefisienkan APBDes sekitar 97\% (Hidayat \& Suaedi, 2019). Beberapa peneliti lain melakukan rancang bangun PJUTS dengan berbasis android (Hikmawan \& Suprayitno, 2018) dan boost converter untuk proses discharging baterai (Febrianto et al., 2018). Implementasi penghematan penerangan jalan umum tenaga surya dengan cara meredupkan lampu yang tidak diperlukan (Ullah \& Oktaviandra, 2020).

Teknologi pembangkit listrik ramah lingkungan dengan memanfaatkan tenaga surya sudah mulai dikenal oleh masyarakat Agrowidya, hanya saja mereka belum bisa mengembangkan aplikasinya pada kehidupan sehari-hari. Potensi sumber energi matahari di kampung ini juga sangat baik, karena tidak banyak terdapat pepohonan tinggi yang menghalangi sinar matahari untuk mencapai tanah. Ide penerangan jalan umum dengan memanfaatkan tenaga surya dapat menjadi salah satu upaya edukasi dan pemberdayaan pada masyarakat Kampung Agrowidya dalam pemanfaatan energi surya guna mencapai cita-cita desa mandiri energi. Ide penerangan jalan umum tenaga surya ini juga sejalan dengan program prioritas nasional yang dicetuskan pemerintah dalam rangka pemenuhan dan pemerataan akses energi bagi seluruh wilayah Indonesia (EBTKE, 2019). Berdasarkan fakta di lapangan dan kajian-kajian terdahulu maka tim pengabdian masyarakat ITERA melaksanakan program pemanfaatan penerangan jalan umum tenaga surya di Kampung Agrowidya Rajabasa Jaya sebagai sebuah alternatif solusi untuk mengatasi minimnya akses penerangan jalan umum di sana.

\section{METODE}

Metode yang digunakan dalam kegiatan pengabdian kepada masyarakat ini secara singkat ditunjukkan pada Gambar 3, antara lain:

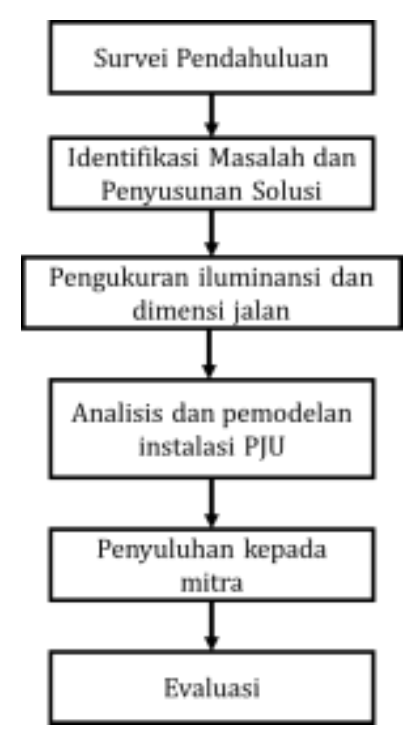

Gambar 3. Diagram alir tahapan pelaksanaan kegiatan pengabdian 


\subsection{Survei Pendahuluan}

Survei dilakukan di beberapa lokasi untuk menemukan jalan yang cocok untuk percontohan. Wawancara dan audiensi dengan perwakilan mitra (seperti yang ditunjukkan pada Gambar 4) dilakukan untuk mendengar masalah penerangan jalan di desa Jalan Agrowidya.

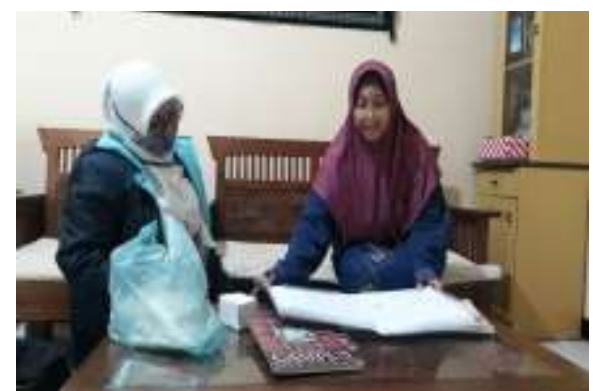

Gambar 4. Audiensi dengan perwakilan mitra

\subsection{Identifikasi Masalah dan Penyusunan Solusi}

Kondisi masyarakat mitra sendiri sebenarnya sudah tersambung dengan listrik PLN, hanya saja masih tergolong masyarakat menengah ke bawah dibuktikan dengan kapasitas meter listrik terpasang yang berkisar 450 - 900 VA. Hal ini menjadi salah satu penyebab mengapa instalasi penerangan jalan umum masih minim. Untuk itu, diusulkan solusi dengan cara memberikan edukasi hemat energi dan pelatihan perencanaan penerangan jalan umum dengan tenaga surya.

\subsection{Pengukuran Iluminansi dan Dimensi Jalan}

Guna mengetahui kondisi eksisting penerangan jalan di Kampung Agrowidya, dilakukan pengukuran langsung parameter iluminansi menggunakan luxmeter di titik-titik vital jalan pada malam hari. Selain itu, juga dilakukan pengukuran dimensi jalan menggunakan laser distance meter. Telah dilakukan pengukuran terhadap tiga titik lokasi yang berjarak 10 meter antar titiknya.

\subsection{Analisis dan Pemodelan Instalasi PJU}

Dari hasil pengukuran parameter iluminansi dan dimensi kemudian disimpulkan bahwa kondisi pencahayaan di jalan utama Kampung Agrowidya belum memenuhi standar SNI 7391:2008 dimana untuk jalan lokal/lingkungan seperti di perkampungan normalnya iluminansi (tingkat pencahayaan) rata-ratanya adalah 5 lux dengan kemerataan 0,1 (Spesifikasi Penerangan Jalan Di Kawasan Perkotaan (Standar Nasional Indonesia 7391 :2008), 2008); sementara di jalan utama Kampung Agrowidya rata-rata iluminansi di bawah 2 lux. Tingkat kemerataan pencahayaan dinyatakan dalam coefficient of uniformity yang merupakan rasio antara iluminansi minimum dengan maksimum (Mandala et al., 2016). Diperoleh tingkat kemerataan jalan di Kampung Agrowidya 0,006. Analisis spesifikasi kebutuhan PJU di kampung Agrowidya dilakukan setelah pengambilan data dimensi jalan dan tingkat pencahayaan di jalan utama. Pemodelan penerangan jalan umum dilakukan dengan menggunakan beberapa opsi pilihan lampu LED, antara lain Philips BRP130, BRP052, dan BRP042 menggunakan software DIALux. Setelah ditemukan model penerangan yang sesuai dengan kebutuhan, lalu dirancang sistem panel surya sebagai penyuplai energi listrik.

\subsection{Penyuluhan Kepada Mitra}

Kegiatan penyuluhan tentang hemat energi dan perencanaan instalasi penerangan jalan umum dilaksanakan tanggal 4 April 2021 secara langsung di depan balai warga. Sosialisasi dihadiri oleh 10 orang warga, 5 anggota pengusul dan 6 mahasiswa ITERA. Kegiatan dilakukan di luar ruangan agar peserta dapat lebih santai dan rileks mendengarkan pemaparan materi. Sebelum penyampaian materi peserta diberi kuesioner pretest untuk menguji tingkat 
pengetahuan peserta terhadap materi yang akan disampaikan. Kemudian anggota tim menyampaikan materi dengan metode ceramah dan demonstrasi. Setelah penyampaian materi peserta diberi kuesioner posttest untuk mengetahui sampai dimana pencapaian peserta terhadap materi setelah mengikuti kegiatan penyuluhan. Error! Reference source not found. menunjukkan dokumentasi kegiatan penyuluhan program pengabdian ini.

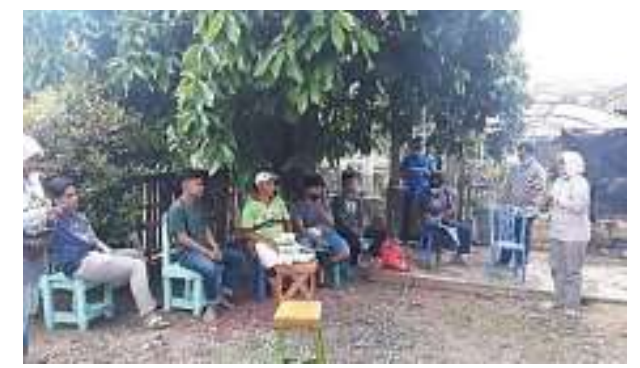

Gambar 5. Penyuluhan dan diseminasi teknologi penerangan jalan umum dengan tenaga surya

\subsection{Evaluasi}

Evaluasi dilakukan setelah kegiatan penyuluhan selesai dilaksanakan. Proses evaluasi berupa pengukuran keberhasilan program dengan menggunakan instrumen kuesioner pre test dan post test. Hasil kuesioner diolah kemudian dianalisis sehingga diperoleh informasi mengenai perubahan sikap dan pengetahuan mitra terkait penerangan jalan umum tenaga surya.

\section{HASIL DAN PEMBAHASAN}

Penerangan jalan umum tenaga surya (PJUTS) merupakan salah salah satu program prioritas nasional. Namun pada implementasinya, jalan-jalan yang sudah terpasang instalasi PJUTS masih terbatas. Jalan dengan status jalan lingkungan seperti di desa dan perkampungan khususnya masih belum tersedia akses terhadap penerangan jalan umum ini. Sementara itu, dari berbagai studi menunjukkan bahwa instalasi PJUTS yang telah terpasang terkadang masih belum memenuhi standar SNI 7391:2008, padahal jika dimanfaatkan dengan baik usaha ini dapat meningkatkan efisiensi penggunaan anggaran daerah/desa (Hidayat \& Suaedi, 2019).

Perencanaan instalasi PJUTS diawali dengan pengukuran langsung kondisi eksisting pencahayaan di jalan Kampung Agrowidya. Berdasarkan hasil pengukuran disimpulkan bahwa kondisi penerangan jalan di Kampung Agrowidya berada di bawah standar SNI 7391:2008. Adapun solusi untuk memenuhi kebutuhan penerangan di jalan Kampung Agrowidya, maka dilakukan analisis dan pemodelan penerangan menggunakan software DIALux. Beberapa opsi digunakan sebagai lampu penerangan, yaitu Philips LED BRP130, BRP052, dan BRP042 dengan parameter tinggi tiang tetap $5 \mathrm{~m}$ dan sudut kemiringan tetap boom $15^{\circ}$. Jenis lampu LED dipilih karena efisiensinya yang tinggi dengan konsumsi listrik rendah dibandingkan dengan lampu jenis SON-T. Terlihat bahwa lampu LED BRP130 adalah opsi yang memenuhi semua kriteria standar SNI 7391:2008, sedangkan dua opsi lainnya, LED BRP052 dan BRP 042, masih belum memenuhi beberapa kriteria seperti luminasi dan kemerataan distribusi pencahayaan.

Tahap perencanaan selanjutnya adalah sistem penyuplai listrik tenaga surya untuk PJU. Lampu Philips LED BRP130 merupakan jenis LED dengan rating daya 70 Watt. Untuk memenuhi suplai listrik pada tiga lampu dirancang sistem panel surya dengan kapasitas $210 \mathrm{Wp}$. Karena penggunaan lampu diperlukan pada malam hari, maka diperlukan media penyimpanan energi berupa baterai/accumulator dengan kapasitas 140Ah. Secara garis besar cara kerja dari sistem instalasi penerangan jalan umum tenaga surya ini ditunjukkan pada Error! Reference source not found.. Sinar matahari yang membawa energi foton ditangkap oleh sel-sel fotovoltaik panel surya, lalu energi cahaya yang terkonversi menjadi energi listrik kemudian dialirkan ke solar charge controller. Solar Charge Controller mengatur pengisian baterai saat siang hari dan menyuplai listrik ke penerangan jalan umum saat malam hari. Inverter digunakan untuk 
mengubah arus DC dari solar charge controller menjadi arus AC untuk digunakan oleh lampu penerangan jalan.

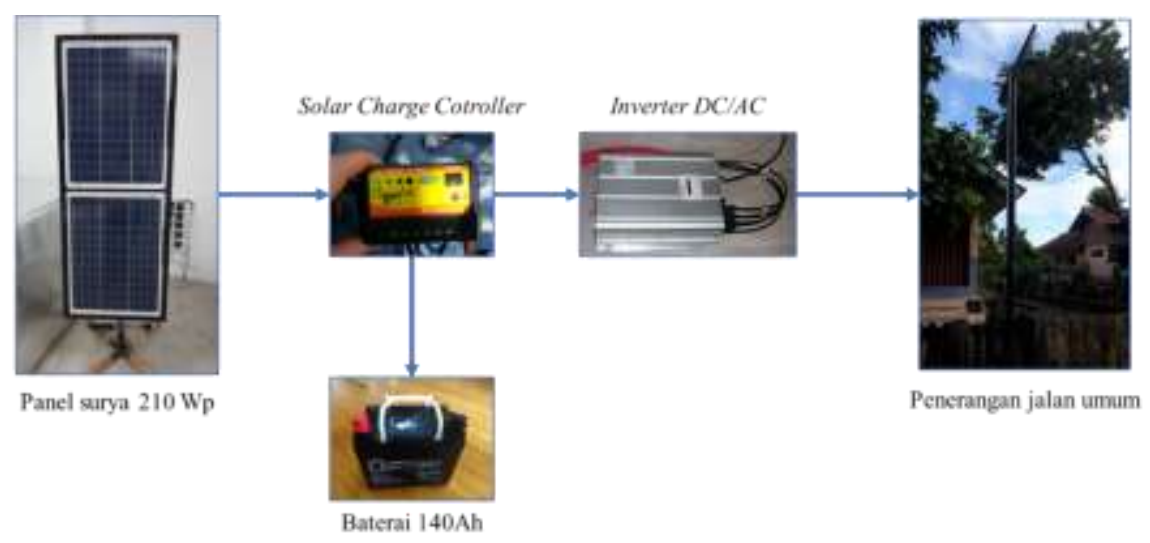

Gambar 6. Skema instalasi penerangan jalan umum tenaga surya

Tabel 1. Persentase tingkat pemahaman masyarakat sebelum dan sesudah kegiatan penyuluhan PJU tenaga surya

\begin{tabular}{|c|c|c|c|}
\hline \multirow[t]{2}{*}{ No } & \multirow[t]{2}{*}{ Aspek observasi } & \multicolumn{2}{|c|}{$\begin{array}{l}\text { Persentase Mitra yang } \\
\text { Paham }\end{array}$} \\
\hline & & $\begin{array}{c}\text { Sebelum } \\
\text { Penyuluhan }\end{array}$ & $\begin{array}{c}\text { Sesudah } \\
\text { Penyuluhan }\end{array}$ \\
\hline 1. & Pengetahuan tentang energi baru terbarukan & $10 \%$ & $100 \%$ \\
\hline 2. & Pengetahuan tentang panel surya & $30 \%$ & $100 \%$ \\
\hline 3. & $\begin{array}{l}\text { Pengetahuan tentang pemanfaatan panel surya di bidang } \\
\text { penerangan jalan umum }\end{array}$ & $20 \%$ & $100 \%$ \\
\hline 4. & $\begin{array}{l}\text { Pengetahuan tentang cara pemanfaatan panel surya } \\
\text { untuk penerangan jalan umum }\end{array}$ & $10 \%$ & $100 \%$ \\
\hline 5. & $\begin{array}{l}\text { Pengetahuan tentang komponen yang dibutuhkan dalam } \\
\text { integrasi panel surya dengan penerangan jalan umum }\end{array}$ & $0 \%$ & $100 \%$ \\
\hline 6. & $\begin{array}{l}\text { Pengetahuan tentang aspek yang perlu diperhatikan } \\
\text { dalam integrasi panel surya dengan penerangan jalan } \\
\text { umum }\end{array}$ & $0 \%$ & $100 \%$ \\
\hline 7. & $\begin{array}{l}\text { Jika kegiatan ini diselenggarakan kembali, saya bersedia } \\
\text { untuk berpartisipasi/terlibat }\end{array}$ & $90 \%$ & $100 \%$ \\
\hline
\end{tabular}

Hasil perencanaan kemudian diseminasikan ke warga/mitra pada kegiatan penyuluhan hemat energi dan pemanfaatan energi matahari sebagai penerangan jalan umum. Sebelum dan sesudah kegiatan penyuluhan dilakukan pengukuran pemahaman masyarakat terkait pemanfaatan energi matahari. Penilaian pemahaman warga dengan menggunakan instrumen kuesioner pre test dan post test. Error! Reference source not found. adalah rekapitulasi hasil pre test dan post test dalam bentuk persentase tingkat pemahaman keseluruhan peserta penyuluhan di Kampung Agrowidya .Hasil pre test menunjukkan bahwa dari 10 orang peserta hanya 1 orang yang mengetahui tentang energi baru dan terbarukan (pertanyaan A), 3 orang yang mengetahui tentang panel surya (pertanyaan B), 2 orang yang mengetahui tentang pemanfaatan panel surya untuk penerangan jalan umum (pertanyaan C), dan 1 orang yang mengetahui cara memanfaatkan energi surya untuk penerangan jalan umum (pertanyaan D). Sedangkan terkait pemahaman yang lebih detail tentang komponen-komponen yang dibutuhkan untuk mengintegrasikan panel surya dengan PJU (pertanyaan E) maupun aspek yang perlu diperhatikan dalam integrasi panel surya dengan penerangan jalan umum (pertanyaan F) belum ada yang mengetahui. Setelah mengikuti penyuluhan terlihat bahwa terjadi peningkatan pemahaman peserta terkait energi baru terbarukan khususnya energi surya untuk penerangan jalan umum. Hal ini terlihat dari hasil post 
test yang menunjukkan bahwa semua peserta telah memahami tentang energi baru dan terbarukan, energi surya, pemanfaatan energi surya untuk penerangan jalan umum, komponenkomponen yang diperlukan dalam membuat instalasi penerangan jalan umum tenaga surya, dan aspek yang perlu diperhatikan dalam integrasi panel surya dengan penerangan jalan umum. Dari hasil analisis kedua instrumen tersebut dapat dikatakan bahwa kegiatan pengabdian ini cukup efektif untuk mengenalkan energi surya sebagai penerangan jalan umum. Terlihat bahwa antusiasme masyarakat terhadap energi surya juga meningkat dengan adanya program penyuluhan pemanfaatan panel surya sebagai penerangan jalan umum (aspek observasi nomor 7).

\section{KESIMPULAN}

Pemanfaatan energi surya sebagai penerangan jalan umum merupakan salah satu upaya alternatif yang efektif untuk akses jalan khususnya jalan lingkungan yang ada di desa atau perkampungan. Pemanfaatan panel surya sebagai penerangan jalan umum di Kampung Agrowidya telah dilakukan guna memenuhi kebutuhan pencahayaan yang sesuai dengan standar SNI 7391:2008. Hasil pemodelan dan analisis spesifikasi kebutuhan pencahayaan di jalan utama Kampung Wisata Agrowidya dengan menggunakan DIALux diperoleh bahwa jenis lampu Philips LED BRP130 dengan tinggi tiang $5 \mathrm{~m}$ dan sudut kemiringan $15^{\circ}$ merupakan model yang cocok untuk jalan utama Kampung Wisata Agrowidya. Sementara untuk sistem suplai listriknya, menggunakan panel surya dengan rating daya $210 \mathrm{Wp}$ dan media penyimpanan energi berupa baterai $140 \mathrm{Ah}$. Hasil penyuluhan terkait penerangan jalan umum tenaga surya ini menunjukkan terjadi peningkatan pemahaman masyarakat mitra terhadap pemanfaatan energi surya untuk penerangan jalan. Selain itu, masyarakat juga menjadi lebih antusias terhadap kegiatan pemanfaatan sumber energi terbarukan di sekitar mereka.

\section{UCAPAN TERIMA KASIH}

Penulis mengucapkan terima kasih kepada Lembaga Penelitian dan Pengabdian kepada Masyarakat Institut Teknologi Sumatera yang telah memberi dukungan finansial terhadap pengabdian ini melalui Hibah Pengabdian kepada Masyarakat 2021.

\section{DAFTAR PUSTAKA}

EBTKE, H. (2019). Dorong Dukungan Pemda, Ditjen EBTKE Sosialisasikan Program PJU-TS Tahun 2020. Website Direktorat Energi Baru Terbarukan Dan Konservasi Energi. https://ebtke.esdm.go.id/post/2019/11/04/2387/dorong.dukungan.pemda.ditjen.ebtke.s osialisasikan.program.pju-ts.tahun.2020?lang=en

Effendi, A., \& Suryana, A. (2013). Evaluasi Sistem Pencahayaan Lampu Jalan Di Kecamatan Sungai Bahar. Jurnal Teknik Elektro ITP, 2(2), 86-94.

Febrianto, R., Soedjarwanto, N., \& Zebua, O. (2018). Rancang Bangun Boost Converter Untuk Proses Discharging Baterai Pada Penerangan Jalan Umum Tenaga Surya ( Pjuts ). Prosiding Seminar Nasional Tekniologi Elektro Terapan 2018, 02(01), 159-164. https://prosiding.polinema.ac.id/sngbr/index.php/sntet/article/view/151

Hidayat, S., \& Suaedi, D. A. (2019). Perawatan Listrik Tenaga Surya untuk Penerangan Jalan Desa Bagi Karang Taruan Desa Glanggang Kecamatan Pakisaji Malang. Jurnal Graha Pengabdian, 1(1), 10-17. http://journal2.um.ac.id/index.php/jgp/article/view/9957/4464

Hikmawan, S. R., \& Suprayitno, E. A. (2018). Rancang Bangun Lampu Penerangan Jalan Umum (Pju) Menggunakan Solar Panel Berbasis Android (Aplikasi Di Jalan Parkiran Kampus 2 Umsida). Elinvo (Electronics, Informatics, and Vocational Education), 3(1), 9-17. https://doi.org/10.21831/elinvo.v3i1.15343 
Mandala, A., Ritva, A., \& Gunawan, R. (2016). Komparasi Metode Perhitungan Pencahayaan Alami (Perhitungan Manual, Simulasi Maket, Dan Simulasi Digital). Lembaga Penelitian Dan Pengabdian Kepada Masyarakat Universitas Katolik Parahyangan 2016.

Spesifikasi penerangan jalan di kawasan perkotaan (Standar Nasional Indonesia 7391 :2008), SNI 7391:2008 1 (2008).

Nurdiana, N. (2017). Evaluasi Iluminasi Lampu Penerangan Jalan Soekarno - Hatta Palembang. Jurnal Ampere, 1(2), 1. https://doi.org/10.31851/ampere.v1i2.896

Ullah, A., \& Oktaviandra, R. M. (2020). Implementasi Penghematan Penerangan Jalan Umum Tenaga Surya ( PJUTS ) di Jalan Kolektor Primer. Seminar Nasional Teknologi Informasi Komunikasi Dan Industri, 356-363. http://ejournal.uinsuska.ac.id/index.php/SNTIKI/article/view/11224 